\title{
Networked Innovation in Innovation Networks: A Home Appliances Case Study
}

\author{
Luis Berasategi, Joseba Arana, and Eduardo Castellano \\ IKERLAN Technological Research Centre \\ PoJ.M. Arizmendiarrieta, 2 0500, Arrasate-Mondragón, Gipuzkoa, Spain \\ \{lberasategi, jmarana, ecastellano\} @ikerlan.es
}

\begin{abstract}
Amongst different types of Collaborative Networked Organizations it is possible to highlight those created to develop and market product, process or business model innovation. In this type of innovation network, which has special characteristics, the challenge is to introduce effective networked innovation in the very same innovation network. This paper presents the main features of TALAI-SAREA ( $)$ methodology that includes a reference model, a set of analysis tools and a method for implementing networked innovation in innovation networks.
\end{abstract}

Keywords: Innovation, Network, Model, Collaborative.

\section{Introduction}

Nowadays, it's quite difficult to think that internal competences and resources of an organization are just sufficient to respond to dynamic market requirements, so that the reason for collaboration [1] and [2]. In any case, with inter-organizational collaboration the need to adjust processes and tools, and achieve a level of trust needed for working together are factors that slow down and endanger, in many cases, the collaboration objectives themselves. Hence the need to constitute Virtual Breeding Environments (VBEs) that raise an organization's degree of preparedness for the agile launch of dynamic Virtual Organizations (VOs), where some VBE partners participate. The combination of these two concepts (VBEs and VOs), as part of the notion of Collaborative Networked Organizations (CNOs), is a powerful mechanism for establishing strategic alliances to create value [3].

There are many kinds of $\mathrm{CNO}$, depending on the criteria selected. A good taxonomy is defined by Camarinha-Matos and Afsarmanesh [3] as a result of the ECOLEAD project. The criteria used in this taxonomy are based on orientation (longterm strategic/goal-oriented), driven aim (grasping opportunity/continuous production), and scope (organizations/professionals), amongst others. From the perspective of their objectives, different kinds of CNO can easily be identified according to their output: either creating new value (innovation), or translating this new value to the market (product/service supply).

In the current global and dynamic environment it seems clear that innovation must constitute a basic element for enhancing the competitiveness of European companies. Implementation of concepts developed under the $\mathrm{CNO}$ paradigm should also serve for 
the development of specific VBEs in the field of innovation, so-called "Innovation Networks" [4].

IKERLAN, based on its empirical knowledge in the field of innovation networks ${ }^{1}$, has developed a methodology to help organizations analyze, design and deploy Networked Innovation. This methodology is called TALAI-SAREA (C) (Berasategi, 2009), and it contains a set of elements that, when treated holistically, allows a truly open networked innovation process to be implemented, one which contemplates the contributions of both organizations and individuals.

This paper presents the most relevant aspects contemplated by the methodology, and the principal key aspects to bear in mind.

\section{State of the Art}

The concept of innovation networks appears from at least Lundvall [5], but it is very recently, during the past few years, when this concept begins to be researched in volume. Roy Rothwell [6] in his work on innovation models already pointed to the fact that the nature of the innovation process evolves towards complex models that require high levels on integration, both on the intra and inter-organizational levels. Recently, Henry Chesbrough [7] complements the vision by coining the term 'Open Innovation' to describe the systematic integration of external inputs at different stages during the innovation process.

Although an unanimously accepted reference framework has not yet been achieved [8], important advances has been made by characterizing the networked innovation process. Kalthoff, Nonaka and Nueno [9] emphasis its informal nature and characterize it as multidimensional and multilevel, and Pyka [10] and Taatila et al. [11] examine its social aspects. These and other authors establish that innovation networks serve to promote creativity, increase the capacity for invention and act as a catalyst for innovation.

There have also been many attempts to categorize innovation networks. Dussauge et al. [12] carried out an initial classification according to field and strategic objectives, and Tidd [13] proposes identifying different types of innovation network according to two axes; radicalism of innovation, and partner similarity. But perhaps the most up to date classification and one that can shed the greatest light on the development of a networked innovation model is that based on criteria related to the sources of innovation. From this perspective, the literature distinguishes between three types of collaboration: (1) External collaborations with other organizations [14], [15] and

${ }^{1}$ IKERLAN's experience in the field of innovation networks arises mainly from its participation in a broad range of research and industrial projects. Some of the more representative are:

(1) Research projects - TNEE (Thematic Network on Extended Enterprises). FP5. GTC32001-63019, K-FLOW (Advanced Methodologies and Tools for the Knowledge Management within the Extended Manufacturing Enterprise). FP5. G1RD-CT-2001-0066, ECOLEAD (European Collaborative Networked Organizations Leadership Initiative). FP6. IP 506958, REMPLANET (Resilient Multi-Plant Networks). FP7. 229333, LURRALDE (CON)ex (Promoting an Innovative Social Culture in the Basque Country for sustainable development). Basque Government 2007/09; (2) Industrial projects - Deployment of innovation networks in different domains: cycles (ORBEA), elevators (ORONA), white-appliances (FAGOR), gas\&oil valves (AMPO), etc. 
[16]; (2) Co-innovations through customers [17], [18], [19], [20], [21] and [22]; (3) Collaborations via Innomediaries; innovation market platforms [23] and [24].

From the perspective of managing innovation networks, the literature includes many approaches, in general more conceptual and descriptive in nature than experience based. Cooperation, coordination, creativity and chaos level are flagged as factors for success. On the other hand, García [25] centers his analysis on the importance of social networks, and Nooteboom [26] on the level of trust.

Particularly interesting from the perspective of empirical research is the work by Ojasalo [27], in which innovation network management patterns are analyzed. The results obtained serve to characterize innovation networks according to two axes, called "Rigid" and "Free".

In any case, and tackling the challenge of creating true networked innovation, there is still a long way to reach a holistic, systematic and integrating vision based on a networked innovation model. A model which embraces the different aspects to be managed taking into account the different collaboration types and with an eminently practical focus. This is the intention of the work presented in this paper.

\section{Methodology}

In developing the research we have based on previous studies identified in the literature, and a case study with a prestigious business group in the white appliance sector. This case study has been developed following an action research approach. Therefore, the research methodology adopted can be classified as a qualitative methodology [28].

Case studies are frequently used for exploratory and theory building research [29] and [30]. The selected case study, FAGOR Electrodomésticos, is mainly comprised of three companies: FAGOR Electrodomésticos S.Coop. located in Spain, FAGOR Brandt located in France, and FAGOR Mastercook located in Poland. Additionally, other subsidiaries participate in its innovation network within and without the electrical appliance sector.

The elements of the model, analysis methodology, and the transformation plan execution have profiled, and been enriched, within an action research type project [31], in order to improve understanding of social and cultural contexts within FAGOR's innovation network [32]. It is action research in the sense that IKERLAN is part of the process and the research directly influences its partner. But this is not a one-way process, the whole approach emphasizes co-creation [33].

\section{TALAI-SAREA Model}

\subsection{General}

IKERLAN, based both on its network research and its empirical knowledge, has developed its own methodology for helping organizations to analyze, design and set up Networked Innovation: it is called TALAI-SAREA - Advanced Techniques for Networked Innovation.

TALAI-SAREA contains: (1) its own reference model; (2) a set of analysis and synthesis tools for contrasting reality at the organization against the reference model, and; (3) the transformation plan necessary for each organization. 
Six focus areas are defined in the model; the network of networks, the strategic orientation, the innovation factory, the collaboration space, the DNA of collaborative innovation and the innovation network scorecard (see Fig. 1).

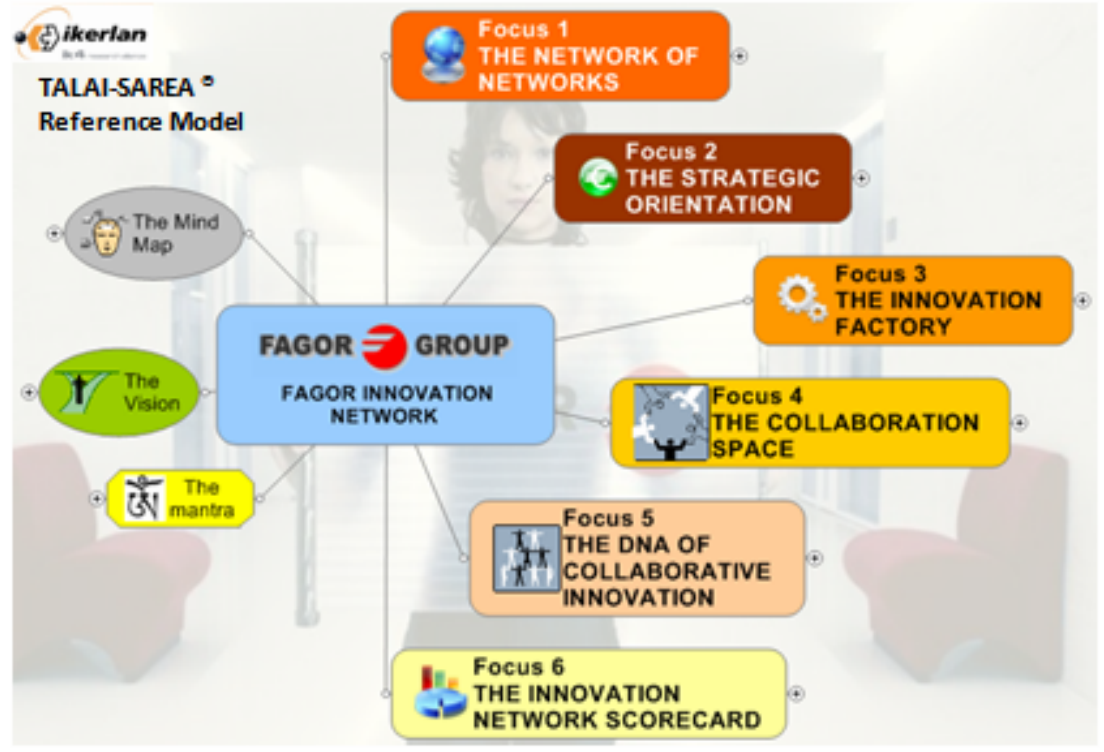

Fig. 1. Focus areas defined in TALAI-SAREA ( $)$ model

The focus areas are axes for transformation where organizations that wish to innovate in a networked way must develop. The key aspects to develop within each focus area are identified (detailed for each focus point in the following points in this section). In many cases, the development of each key aspect can be configured as a subproject or workshop (we also call these "interventions").

The following are described for each aspect; objective, activities and actors implicated, content and form adopted by final result, set of methodologies and support tools and keys to success.

TALAI-SAREA seeks to develop integration as a key element of networked innovation:

- Holistic integration of activities (government, strategy, process, infrastructures and cultural) that require networked innovation.

- Integration of implicated organizations and bodies (internal and external).

- Persona integration (customers, workers, professionals, etc.) in open networks.

In the methodology, analysis of the situation of networked innovation in the organization leads to the identification and prioritization of key aspects to develop. The transformation plan within TALAI-SAREA implementation in FAGOR becomes a node project from which new interventions are developed (in the form of workshops and 
sub-projects), what orders, and integrates, other interventions currently under way. Such interventions are identified within the reference framework provided by the TALAI-SAREA model axes.

\subsection{Focus 1: The Network of Networks}

The network of networks describes the activities required by new organization to cease being isolated entities within a domestic space and become nodes within a global space. Interventions are included to:

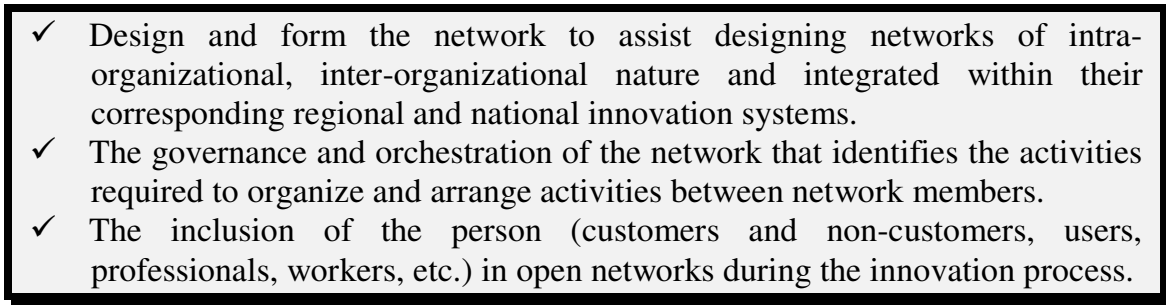

Some of the key aspects are:

- Avoid hyperconnectivity and maintain ties outside the organization ("structural holes") [34].

- Adopt a light, efficient not excessively bureaucratized focus.

- Once the network is operational, don't stand still; continue orchestrating.

- Move from a Firm-Centric perspective to an individual (person) centric perspective and network [35].

- Adopt clear and shared IPR management strategies.

- Integrate the external open network activities with the internal innovation process.

\subsection{Focus 2: The Strategic Orientation}

The strategic orientation focus includes all interventions necessary to set a shared direction for activities in the innovation network system that are correctly aligned with strategy. Initially these activities are:

$\checkmark \quad$ The strategic positioning that identifies, according to markets and product typologies the best strategy (leader, follower, etc.) for networked organizations.

$\checkmark$ The configuration of the innovation portfolio presents the correct mix of projects with different horizons for each product-market.

$\checkmark$ The Roadmapping of the network focuses strategy on the innovation of products-services in concordance with: (a) the opportunities and threats in the environment, and; (b) the development, based on projects and collaborations, of technological competences. 
Some issues of interest:

- Innovation is undoubtedly linked with strategy. The highest levels of involvement and leadership correspond to management teams.

- The creative process implicit in innovation is neither at odds nor restricted by strategic orientation. Furthermore, in the absence of infinite resources, strategy is needed to focus effort. Strategy is effective when the money invested in innovations projects is finally shared out.

- Strategy should not be an obstacle for an organization with a well-trained innovation culture going beyond initial goals and taking advantage of new opportunities in areas, a priori, not contemplated by strategy.

- The Roadmap is an excellent strategic definition and communication tool. Its content should be shared and sufficiently internalized by the members of the core network group.

\subsection{Focus 3: The Innovation Factory}

The innovation factory includes all interventions within the network innovation process under parameters of integration, efficiency and effectiveness when obtaining results. Such interventions are included in:

The networked innovation process that describes the activities (innovation watch, identification of business opportunities, generation of innovative concepts and management of innovation portfolio) within a process of innovation in which multiple agents can participate from the network of networks.

$\checkmark$ The innovation portfolio that describes the management activities for all the assets generated in the process (ideas, projects, products and innovative services).

Some of the key aspects are:

- Innovation is not just linked to the creation of "new things", like applying technology to products; on many occasions the best opportunities come from reconsidering other aspects: services, customer experience, value proposition, brand, etc.

- Although we know that innovation is also linked to chance and uncertainty we have wanted to use the name "the Innovation Factory" to reinforce the importance of articulating innovation according to parameters of efficiency and effectiveness when obtaining results.

- One of the greatest obstacles inherent in the innovation process is the slowness of the project development phase [36]. We must organize ourselves to develop innovations rapidly within a clear and shared process.

- The innovation process is not a linear process.

- It is important to manage all assets (opportunities, ideas, concepts and innovation projects) produced throughout the process. 


\subsection{Focus 4: The Collaboration Space}

The collaboration space includes activities to construct the environment and infrastructure necessary to support the correct execution of network activities within the innovation process. This initially includes the following key aspects:

\footnotetext{
$\checkmark \quad$ The digital space that describes the characteristics and resources necessary for the virtual workspace in the ICT application.

$\checkmark \quad$ The physical space that describes the characteristics and resources necessary within the physical workspace.

$\checkmark \quad$ The social network, which describes the key aspects for designing a network between individuals that empowers interrelation, trust and obtaining results.
}

Some of the key aspects are:

- The approach should be light and focused on action, it not always being necessary to employ sophisticated IT systems for network operation.

- Useful, ready to use, applications are required, which seek interoperability with other systems already operating at the organizations.

- It is important to guarantee controlled security.

- Social networks must be actively managed. They are in large part one of the keys for obtaining high levels of network operation performance.

- The collaboration space must mix virtual interaction with face-to-face interaction, ensuring the necessary development of team feeling.

\subsection{Focus 5: The DNA of Collaborative Innovation}

The DNA of collaborative innovation contains interventions that lead to the conditioning and transformation of a culture favorable to networked innovation. Initially it includes the following key aspects:

\footnotetext{
$\checkmark$ The network/community culture where basically the amplifiers and inhibitors of a network collaboration culture are analyzed.

$\checkmark$ The innovation culture where were basically the amplifiers and inhibitors of a culture promote efficient and effective innovation.

$\checkmark \quad$ The cooperative culture where basically those amplification and inhibition aspects that in a cooperative culture may affect networked innovation.
}

Some of the key aspects are:

- The cornerstone of network working is the generation of trust between all network agents.

- Promote human relations.

- $\quad$ Share the same mind map, common language, but observing diversity.

- Manage uncertainly inherent in innovation and anxiety.

- Adopt an intra-entrepreneurial temperament in all members of the network of networks.

- Gather aspects that promote innovation that originate from the concept of cooperative organization, such as the sense of identity. 


\subsection{Focus 6: The Innovation Network Scorecard}

The innovation network scorecard includes measurement and monitoring activities for network innovation systems. The activities revolve around the development of:

The network scorecard, which gathers the evolution of critical indicators for governance and network orchestration, for the operation of the overall process and for the use of the collaboration space.

$\checkmark$ The innovation scorecard to measure the amount and quality of knowledge assets generated during the process, and their impact on the business and activity of organizations.

Remember that:

- The innovation network scorecard is the best test for the proper operation of the innovation system as a whole.

- The number and quality of indicators used to construct scorecards must be selected carefully. The scorecard must contain little, but valuable information.

\section{Conclusions}

TALAI-SAREA obviously is not conceived as a closed model for universal application but basically as a practical approach that organizations could use to correctly guide the implementation of the Networked Innovation process. This approach takes into account innovation related practices and activities that many organizations already have, and require integration. Its main value comes from the orchestration of existing tools and practices in a holistic, systematic and integrating vision, taking into account different collaboration types.

From an Innovation Networks viewpoint, some differences with regards the generic model of VBE raise. The strategic alliance, in the case of Innovation Networks, is not only based on preparation for launching concrete initiatives (Virtual Organizations), but also on the following: (1) Clear and common strategy definition shared among partners; (2) Effective orchestration of different activities involved in the innovation process, also including the aforementioned strategic definition and innovation portfolio management, and; (3) The appropriate DNA that enhances the innovation collaboration culture. The challenge and opportunity, arises from the establishment of a true 'Networked Innovation' process inside the 'Innovation Network'.

\section{References}

1. Hagedoorn, J.: Inter-firm R\&D partnerships: An overview of major trends and patterns since 1960. Research Policy 31, 477-492 (2002)

2. Hoffmann, V.E., Molina-Morales, F.X., Martinez-Fernandez, M.T.: Redes de empresas: uma proposta de tipologia para sua classificação. Encontro nacional dos programas de pósgraduação em administração, Curitiba 28 (2004) 
3. Camarinha-Matos, L.M., Afsarmanesh, H.: Collaborative Networked: Reference Modeling. Springer, Heidelberg (2008)

4. Arana, J., Berasategi, L., Aranburu, I.: Collaborative Innovation Networks Management in the Elevation Sector. eChallenges Conference. The Hague (2007)

5. Lundvall, B.A.: Innovation as an interactive process: from user-producer interaction to nacional systems of innovation, pp. 349-369. Technical change and economic theory, London (1988)

6. Rothwell, R.: Successful industrial innovation: critical factors for the 1990s. R\&D Management 22-3, 221-239 (1992)

7. Chesbrough, H.: Open Innovation: The New Imperative for Creating And Profiting from Technology. Harvard Business School Press (2003)

8. Oliver, A.L., Ebers, M.: Networking network studies: an analysis of conceptual configurations in the study of inter-organizational relationships. Organization Studies 19-4, 549-586 (1998)

9. Kalthoff, O., Nonaka, I., Nueno, P.: La luz y la sombra. La innovación en la empresa y sus formas de gestión. Deusto, Bilbao (1998)

10. Pyka, A.: Innovation networks in economics: From the incentive-based to the knowledgebased approaches. European Journal of Innovation Management 5-3, 152-163 (2002)

11. Taatila, V.P., Suomala, J., Siltala, R., Keskinen, S.: Framework to study the social innovation networks. European Journal of Innovation Management 9-3, 312-326 (2006)

12. Dussauge, P., Hart, S., Ramanantsoa, B.: Strategic Technology Management. John Wiley \& Sons, London (1992)

13. Tidd, J.: A review of innovation models. Imperial Collage London (2006)

14. Gulati, R., Nohria, N., Zaheer, A.: Strategic networks. Strategic Management Journal 21-3, 203-215 (2000)

15. Contractor, F.J., Lorange, P.: Cooperative strategies and alliances. Emerald Group Publishing (2002)

16. Dilk, C., Gleich, R., Wald, A.: State and development of innovation networks. Management Decision 46-5, 691-701 (2008)

17. Cox, H., Mowatt, S.: Consumer-driven innovation networks and e-business management systems. Qualitative Market Research: An International Journal 7-1, 9-19 (2004)

18. Surowiecki, J.: The Wisdom of Crowds: Why the Many Are Smarter Than the Few and How Collective Wisdom Shapes Business. Economies, Societies and Nations. Abacus, London (2005)

19. Hippel, E.V.: Democratizing Innovation. MIT Press, Cambridge (2006)

20. Howe, J.: The Rise of Crowdsourcing. WIRED, 14 (2006)

21. Ogawa, S., Piller, F.T.: Collective Customer Commitment: Reducing the risks of new product development. MIT Sloan Management Review 47 (2006)

22. Tapscott, D.: Wikinomics: How Mass Collaboration Changes Everything. Portfolio Hardcover (2008)

23. Piller, F.T.: Interactive value creation with users and customers. Ideas for Innovative Leaders from the Peter Pribilla Foundation (2008)

24. Huston, L., Sakkab, N.: Connect and Develop: Inside Procter \& Gamble's New Model for Innovation. Harvard Business Review (March 2006)

25. García, A.: Procesos de coordinación inter-empresa en la industria automotriz: un estudio de casos. Avance de tesis presentado en el Doctorado de Estudios Organizacionales, UAM-I (2003)

26. Nooteboom, B., et al.: Learning and innovation in organizations and economies. Oxford University Press, London (2000) 
27. Ojasalo, J.: Key network management. Industrial Marketing Management 33, 195-204 (2004)

28. Myers, M.D.: Qualitative Research in Business \& Management. Sage Publications, London (2009)

29. Eisenhardt, K.M.: Building Theories from Case Study Research. Academy of Management Review 14-4, 532-550 (1989)

30. Yin, R.K.: Case Study Research, Design and Methods, 3rd edn. Sage Publications, Newbury Park (2002)

31. Susman, G.I.: Action Research: A Sociotechnical Systems Perspective. In: Morgan, G. (ed.). Sage Publications, London (1983)

32. Rapoport, R.N.: Three Dilemmas in Action Research. Human Relations 23-6, 499-513 (1970)

33. Whyte, W.F. (ed.): Participatory Action Research. Sage Publications, New York (1991)

34. Burt, R.: Structural Holes: The Social Structure of Competition. Harvard University Press (1995)

35. Prahalad, C.K., Ramaswamy, V.: The Future of Competition: Co-Creating Unique Value with Customers. Harvard Business School Press (2004)

36. BW, BCG. The World's Most Innovative Companies. Business Week SPECIAL REPORT INNOVATION ( April 24, 2006),

http: //www.businessweek.com/magazine/toc/06_17/

B39810617innovation.htm 